\title{
ASSOCIATION BETWEEN QUALITY OF HEALTH SERVICE AND PATIENT SATISFACTION AT JAGAKARSA HOSPITAL
}

\author{
Cicilya Candi, Dewi Mustika, Kurnia Sari
}

Master Program in Public Health, Universitas Indonesia

\begin{abstract}
Background: Quality of health care is defined as the degree of health care performance in relation to a set of define standard, including safety and capacity to improve health within the available resource. Patients demand high-quality services as such services affect patient satisfaction. This study aimed to determine the association between quality of health service and patient satisfaction at Jagakarsa Hospital.

Subject and Method: This was cross-sectional study conducted at Jagakarsa Hospital. Total of 150 in-patients were selected for this study. The dependent variable was patient satisfaction. The independent variable was quality of health service with several dimensions: (1) Reliability; (2) Responsiveness; (3) Empathy; and (4) Tangibles. The data were collected by questionnaire. The data were analyzed by a multiple logistic regression.

Results: Patient satisfaction was associated with all dimensions of health service quality, including reliability, responsiveness, empathy, and tangibles.

Conclusion: Patient satisfaction is associated with all dimensions of health service quality, including reliability, responsiveness, empathy, and tangibles.
\end{abstract}

Keywords: patient satisfaction, quality of service

Correspondence:

Cicilya Candi. Masters Program in Public Health, Universitas Indonesia, Depok, West Java. Email: cicilya.candi@alumni.ui.ac.id. Mobile: 085281428636.

The $6^{\text {th }}$ International Conference on Public Health Best Western Premier Hotel, Solo, Indonesia, October 23-24, 2019 | 281 